\title{
REGN-COV2 antibodies prevent and treat SARS-CoV-2 infection in rhesus macaques and hamsters
}

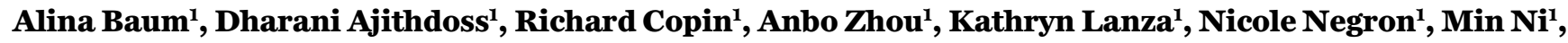 \\ Yi Wei', Kusha Mohammadi', Bret Musser'1, Gurinder S. Atwal' ${ }^{1}$, Adelekan Oyejide', Yenny Goez-Gazi ${ }^{2}$, \\ John Dutton ${ }^{2}$, Elizabeth Clemmons ${ }^{2}$, Hilary M. Staples ${ }^{2}$, Carmen Bartley ${ }^{2}$, Benjamin Klaffke ${ }^{2}$, Kendra Alfson ${ }^{2}$, \\ Michal Gazi ${ }^{2}$, Olga Gonzalez ${ }^{2}$, Edward Dick Jr. ${ }^{2}$, Ricardo Carrion Jr. ${ }^{2}$, Laurent Pessaint ${ }^{3}$, Maciel Porto ${ }^{3}$, \\ Anthony Cook ${ }^{3}$, Renita Brown ${ }^{3}$, Vaneesha Ali ${ }^{3}$, Jack Greenhouse ${ }^{3}$, Tammy Taylor ${ }^{3}$, Hanne Andersen ${ }^{3}$, \\ Mark G. Lewis ${ }^{3}$, Neil Stahl' ${ }^{1}$, Andrew J. Murphy ${ }^{1}$, George D. Yancopoulos ${ }^{1}$, Christos A. Kyratsous ${ }^{1 *}$ \\ ${ }^{1}$ Regeneron Pharmaceuticals, Inc., Tarrytown, NY 10591, USA. 2Southwest National Primate Research Center, Texas Biomedical Research Institute, San Antonio, TX 78245 , \\ USA. ${ }^{3}$ BIOQUAL, Rockville, MD 20850, USA \\ *Corresponding author. Email: christos.kyratsous@regeneron.com
}

An urgent global quest for effective therapies to prevent and treat COVID-19 disease is ongoing. We previously described REGN-COV2, a cocktail of two potent neutralizing antibodies

(REGN10987+REGN10933) targeting non-overlapping epitopes on the SARS-CoV-2 spike protein. In this report, we evaluate the in vivo efficacy of this antibody cocktail in both rhesus macaques, which may model mild disease, and golden hamsters, which may model more severe disease. We demonstrate that REGNCOV-2 can greatly reduce virus load in lower and upper airways and decrease virus induced pathological sequelae when administered prophylactically or therapeutically in rhesus macaques. Similarly, administration in hamsters limits weight loss and decreases lung titers and evidence of pneumonia in the lungs. Our results provide evidence of the therapeutic potential of this antibody cocktail.

Fully human monoclonal antibodies are a promising class of therapeutics against SARS-CoV-2 infection (1). To date, multiple studies have described discovery and characterization of potent neutralizing monoclonal antibodies targeting the spike glycoprotein of SARS-CoV-2 (2-11). However, evaluation of the efficacy of these antibodies in vivo is only beginning to emerge, and has largely focused on the prophylactic setting $(6,10,12)$. Furthermore, as the animal models of SARS-CoV-2 infection and COVID-19 disease are still being developed, no single model has emerged as being more relevant for human disease. Indeed, based on the extremely diverse manifestations of COVID-19 in humans, multiple animal models may be needed to mimic various settings of human infection. The rhesus macaque model is widely used to assess efficacy of therapeutics and vaccines and displays a transient and mild course of the disease (13-20). On the contrary, the golden hamster model manifests a much more severe form of the disease, accompanied by rapid weight loss and severe lung pathology (21-23).

We previously described a cocktail of two fully human antibodies, REGN10933 and REGN10987, that bind to spike protein, potently neutralize SARS-CoV-2 and were selected as components of anti-viral antibody cocktail (REGN-COV2) to safeguard against mutational virus escape $(8,9)$. In this study, we used two different animal models, rhesus macaque and golden hamster, that capture the diverse pathology of
SARS-CoV-2 infection and evaluated the in vivo efficacy of this antibody cocktail when used prophylactically or therapeutically. This assessment allows us to compare performance of the antibodies in diverse disease settings to more comprehensively understand the mechanisms by which monoclonal antibody therapies may limit viral load and pathology in infected individuals.

To evaluate the ability of REGN-COV2 to protect rhesus macaques from SARS-CoV-2 infection we initially assessed the impact of antibody administration prior to virus challenge (NHP Study \#1). Six animals were dosed with $50 \mathrm{mg} / \mathrm{kg}$ of REGN-COV2 $(25 \mathrm{mg} / \mathrm{kg}$ of each antibody) and six with placebo, through intravenous administration and challenged with $1 \times 10^{\wedge} 5 \mathrm{PFU}$ of virus through intranasal and intratracheal routes 3 days post mAb dosing. Due to the relatively transient nature of the SARS-CoV-2 infection in rhesus macaques, the in-life portion of the study was limited to 5 days. To determine the impact of mAb prophylaxis on viral load in upper and lower airways we collected nasopharyngeal swabs on a daily basis and bronchoalveolar lavage (BAL) fluid on days 1,3 , and 5 post-challenge (Fig. 1A). Both genomic RNA and subgenomic RNA (which is made during replication) were measured to assess the impact of mAb prophylaxis on the dynamics of viral replication; while genomic RNA (gRNA) may reflect remaining viral inoculum as well as newly replicating virus, subgenomic RNA (sgRNA) should only result 
from newly replicating virus. For placebo-treated animals, the kinetics of viral load measures was as previously reported, with peak in viral load on day 2 post-challenge, although the majority of animals were still positive for viral RNA in nasal swabs on day 5; while the kinetics of gRNA and sgRNA were similar, sgRNA levels were about a hundred-fold lower, consistent with what others have reported $(6,15,16,18)$. For animals receiving REGN-COV2 prophylaxis we observed accelerated clearance of gRNA with almost complete ablation of sgRNA in the majority of the animals, showing that REGNCOV2 can almost completely block establishment of virus infection; this pattern was observed across all measurements in both nasopharyngeal swabs and BAL compared to placebo animals, demonstrating that mAbs administered prophylactically can greatly reduce viral load in both upper and lower airways (Fig. 1B).

A second prophylaxis study (NHP Study \#2) was designed to test whether REGN-COV2 could protect against a 10-fold higher viral inoculum $\left(1.05 \times 10^{\wedge} 6 \mathrm{PFU}\right)$ and compared four animals treated with the $50 \mathrm{mg} / \mathrm{kg}$ dose of REGN-COV2 $(25 \mathrm{mg} / \mathrm{kg}$ of each antibody) with four animals treated with a much lower dose of $0.3 \mathrm{mg} / \mathrm{kg}$ and four animals which were administered placebo (Fig. 2A). Nasopharyngeal and oral swabs were collected and used to measure virus genomic and subgenomic virus RNA. BAL samples were not collected in this study to minimize potential impact of the procedure on histopathological analysis of the lung tissue. We observed that $50 \mathrm{mg} / \mathrm{kg}$ of REGN-COV2 administered 3 days prior to virus challenge was once again able to minimize virus replication even when animals were challenged with this 10-fold higher viral challenge (Fig. 2B), while the prophylactic effect was greatly diminished with the $0.3 \mathrm{mg} / \mathrm{kg}$ dose. Interestingly, in this study we observed increased impact of $\mathrm{mAb}$ treatment on viral load in oral swabs versus nasopharyngeal swabs, potentially indicating that $\mathrm{mAb}$ treatment may impact different physiological sources of virus replication differentially. Additional studies in animal models and humans will be needed to assess this.

Next, we assessed the impact of REGN-COV2 in the treatment setting by dosing four animals challenged with the higher $1 \times 10^{\wedge} 6 \mathrm{PFU}$ of SARS-CoV-2 virus at 1-day post-infection with $25 \mathrm{mg} / \mathrm{kg}$ or $150 \mathrm{mg} / \mathrm{kg}$ of the antibody cocktail (Fig. $2 \mathrm{~A})$. By day 1 post-challenge the animals already reached peak viral load as measured by both genomic and subgenomic RNA, mimicking a likely early treatment clinical scenario of COVID-19 disease, since it has been shown that most SARSCoV-2 infected individuals reach peak viral loads relatively early in the disease course and often prior or just at start of symptom onset $(24,25)$. Compared to four placebo treated animals, REGN-COV2 treated animals displayed accelerated viral clearance in both nasopharyngeal and oral swabs samples, including both genomic and subgenomic RNA samples
(Fig. 2C), clearly demonstrating that the monoclonal antibody cocktail can impact virus load even when administered post infection. Similar to the prophylaxis study, the decrease in viral load appeared more dramatic in oral swabs versus nasopharyngeal swabs. Both treatment groups displayed similar kinetics of virus clearance, suggesting that $25 \mathrm{mg} / \mathrm{kg}$ and $150 \mathrm{mg} / \mathrm{kg}$ demonstrate similar efficacy in this study. The treated animals in the $150 \mathrm{mg} / \mathrm{kg}$ group displayed approximately 10-fold higher titers on day 1 , at the time of mAb administration, therefore potentially masking enhanced effect of a higher drug dose. Similar impact of mAb treatment was observed on genomic and subgenomic RNA for both NP and oral samples, indicating the mAb treatment is directly limiting viral replication in these animals (Fig. 2C).

The two antibody components of REGN-COV2 were selected to target non-overlapping sites on the spike protein to prevent selection of escape mutants, which were readily detectable with single mAb treatment (9). To assess whether any signs of putative escape mutants are observed in an in vivo setting with authentic SARS-CoV-2 virus, we performed RNAseq analysis on all RNA samples obtained from all animals from the study. Analysis of the spike protein sequence identified mutations in NHP samples that were not present in the inoculum virus (fig. S1) further indicating that the virus is actively replicating in these animals. However, we did not observe any mutations that were unique to treated animals; all identified mutations were either present in the inoculum or in both treated and placebo animals, indicating that they were likely selected as part of virus replication in NHPs and were not selected by mAb treatment.

We next performed pathology analyses of lungs of infected animals. All four placebo monkeys showed evidence of lung injury characterized in three monkeys by interstitial pneumonia (Fig. 2D), with minimal to mild infiltration of mononuclear cells (lymphocytes and macrophages) in the septa, perivascular space, and/or pleura. In these three animals, the distribution of lesions was multifocal and involved 2-3 of the 4 lung lobes. Accompanying these changes were alveolar infiltration of lymphocytes, increased alveolar macrophages, and syncytial cells. Type II pneumocyte hyperplasia was also observed in occasional alveoli. In the fourth placebo monkey, lung injury was limited to type II pneumocyte hyperplasia, suggestive of a reparative process secondary to type I pneumocyte injury. Overall, the histological lesions observed in the placebo animals were consistent with an acute SARSCoV-2 infection. In the prophylactic groups, 3 of 4 animals in the low dose $(0.3 \mathrm{mg} / \mathrm{kg})$ and 1 of 4 animals in the high dose $(50 \mathrm{mg} / \mathrm{kg})$ groups showed evidence of interstitial pneumonia (table S1) that was generally minimal and with fewer histological features when compared to the placebo group. In the one affected high dose group animal, only 1 of the 4 lung lobes had a minimal lesion. In the therapeutic treatment 
groups, 2 of 4 low dose $(25 \mathrm{mg} / \mathrm{kg})$ and 2 of 4 high dose $(150 \mathrm{mg} / \mathrm{kg})$ treated animals showed evidence of interstitial pneumonia. In all affected low and high dose animals, only 1 of 4 lung lobes had lesions. Finally, there was no drug related toxicities observed at any of the doses tested. In summary, the incidence of interstitial pneumonia (number of animals as well as number of lung lobes affected) and the severity were reduced in both prophylactic and therapeutic treatment modalities, compared to placebo. The analyses demonstrated that prophylactic and therapeutic administration of REGNCOV2 greatly reduced virus induced pathology in rhesus macaques and showed a clean safety profile.

Unlike rhesus macaques which present with a mild clinical course of disease and transient virus replication when infected with SARS-CoV-2, which may mimic mild human disease, the golden hamster model is more severe, with animals demonstrating readily observable clinical disease, including rapid weight loss accompanied by very high viral load in lungs, as well as severe lung pathology. Thus, this model may more closely mimic more severe disease in humans, although more extensive characterization of this model and severe human disease is needed to better understand similarities and differences in pathology. To evaluate the ability of REGN-COV2 to alter the disease course in this model, we designed a study which evaluated the prophylactic and treatment efficacy of the antibodies (Fig. 3A). In the prophylactic study, twenty-five hamsters were divided into 5 arms (five animals in each). Administration of 50,5 or $0.5 \mathrm{mg} / \mathrm{kg}$ of REGN-COV2 2 days before challenge with $2.3 \times 10^{\wedge} 4$ PFU dose of SARS-CoV-2 virus resulted in dramatic protection from weight loss at all doses. This protection was accompanied by decreased viral load in the lungs at the end of the study in majority of treated animals (day 7 post infection) (Fig. 3C). Evaluation of lung tissues from infected hamsters that were prophylactically treated with placebo or isotype control drug revealed distorted alveoli lined by swollen, hyperplastic type II pneumocytes interspersed with occasional type I single cell necrosis and the alveolar spaces were filled with large numbers of lymphocytes, macrophages, and neutrophils, occasional syncytial cells, and hemorrhage. These changes were accompanied by variably severe interstitial pneumonia characterized by mixed cell inflammation (lymphocytes, macrophages, and neutrophils) in the alveolar septa and perivascular spaces accompanied by edema and septal fibrosis. The severity and incidence of alveolar infiltration and interstitial pneumonia were greatly reduced in animals that received REGN-COV2 (Fig. 3D). Compared with placebo and isotype treated animals, the percent area of pneumonia in the lungs determined using HALO image analysis software was significantly reduced in all REGN-COV2 treated animals irrespective of doses. Intriguingly, we did observe high gRNA and sgRNA levels in the lungs of a few treated animals, although these individual animals did not show decreased protection from weight loss or more extensive pathology than the animals with much lower viral loads. It is possible that mAb treatment may provide additional therapeutic benefit in this model not directly associated with viral load decrease. Alternatively, it is possible that the increased detected viral RNA may not necessarily be associated with infectious virus. As viral replication and lung pathology in the hamster model occur very rapidly, the treatment setting represents a high bar for demonstrating therapeutic efficacy. We used twenty-five hamsters (five in each of five arms) in a therapeutic study and were able to observe therapeutic benefit in animals treated with $50 \mathrm{mg} / \mathrm{kg}$ and $5 \mathrm{mg} / \mathrm{kg}$ doses of REGN-COV2 combination 1-day post viral challenge (Fig. 3B).

Taken together the two hamster studies clearly demonstrate that REGN-COV2 can alter the course of infection in the hamster model of SARS-COV-2 either when administered prophylactically or therapeutically.

In this study, we assessed the in vivo prophylactic and treatment efficacy of the REGN-COV2 mAb cocktail in two animal models, one of mild disease in rhesus macaques and one of severe disease in golden hamsters. Our results demonstrated that the antibodies are efficacious in both animal models, as measured by reduced viral load in the upper and lower airways, reduced virus induced pathology in the rhesus macaque model, and by limited weight loss in the hamster model.

The ability of REGN-COV2 to almost completely block detection of subgenomic species of SARS-COV-2 RNA in rhesus macaques matches or exceeds the effects recently shown in vaccine efficacy studies using the same animal models (18$20,26,27)$. Additionally, the observed accelerated reduction of upper airway virus load in rhesus macaques treated with REGN-COV2 contrasts the lack of impact on viral load in remdesivir treated animals, where reduced viral load could only be observed in lower airways with no differences in nasal viral RNA levels (28). These findings highlight the therapeutic potential of REGN-COV2 to both protect from and treat SARS-COV-2 disease. Additionally, the impact of REGNCOV2 prophylaxis on viral RNA levels in nasopharyngeal and oral swabs may indicate the potential to not only prevent disease in the exposed individual but also to limit transmission.

Importantly, in our studies we did not observe any signs of increased viral load or worsening of pathology in presence of antibodies at either high or low doses in either animal model. Potential for antibody mediated enhancement of disease (ADE) is a serious concern for antibody-based therapeutics and vaccines. And although a recent report showed ability of some anti-spike mAbs to mediate pseudovirus entry into Fc $\gamma \mathrm{R}$ expressing cell lines, these data do not address whether similar behavior would be observed with authentic SARS-CoV-2 virus and primary immune cells (29). Our results 
are consistent with no evidence of enhanced disease in clinical studies assessing convalescent plasma therapy (30).

Similarly to most in vivo data generated to date, our in vivo studies were conducted with the D614 spike protein variant of the SARS-CoV-2 virus. Global shift in circulating SARS-CoV-2 to the D614G variant will likely necessitate a transition to use of that variant for in vitro and in vivo studies with SARS-CoV-2 virus in the future (31). It is yet not established if pathogenicity and replication dynamics of this variant differ in vivo, and it is equally unclear whether there is an association with severity of human infections (32-34). Importantly, we have previously demonstrated that neutralization potency of REGN10933 and REGN10987 as well as REGN-COV2 combination was not altered in the presence of this variant making it likely that the efficacy of REGN-COV2 combination will extend to the $614 \mathrm{G}$ virus $(8,35)$.

In conclusion, our data provide evidence that REGNCOV2 based therapy may offer clinical benefit in both prevention and treatment settings of COVID-19 disease, where it is currently being evaluated (clinicaltrials.gov NCT04426695, NCT04425629 and NCT 04452318).

\section{REFERENCES AND NOTES}

1. J. Cohen, The race is on for antibodies that stop the new coronavirus. Science 368 564-565 (2020). doi:10.1126/science.368.6491.564 Medline

2. B. Ju, Q. Zhang, J. Ge, R. Wang, J. Sun, X. Ge, J. Yu, S. Shan, B. Zhou, S. Song, X. Tang, J. Yu, J. Lan, J. Yuan, H. Wang, J. Zhao, S. Zhang, Y. Wang, X. Shi, L. Liu, J. Zhao, X. Wang, Z. Zhang, L. Zhang, Human neutralizing antibodies elicited by SARS-CoV-2 infection. Nature 584, 115-119 (2020). doi:10.1038/s41586-0202380-z Medline

3. D. Pinto, Y.-J. Park, M. Beltramello, A. C. Walls, M. A. Tortorici, S. Bianchi, S. Jaconi, K. Culap, F. Zatta, A. De Marco, A. Peter, B. Guarino, R. Spreafico, E. Cameroni, J. B. Case, R. E. Chen, C. Havenar-Daughton, G. Snell, A. Telenti, H. W. Virgin, A. Lanzavecchia, M. S. Diamond, K. Fink, D. Veesler, D. Corti, Cross-neutralization of SARS-CoV-2 by a human monoclonal SARS-CoV antibody. Nature 583, 290-295 (2020). doj:10.1038/s41586-020-2349-y Medline

4. C. Wang, W. Li, D. Drabek, N. M. A. Okba, R. van Haperen, A. D. M. E. Osterhaus, F. J. M. van Kuppeveld, B. L. Haagmans, F. Grosveld, B.-J. Bosch, A human monoclonal antibody blocking SARS-CoV-2 infection. Nat. Commun. 11, 2251 (2020). doi:10.1038/s41467-020-16256-y Medline

5. Y. Cao, B. Su, X. Guo, W. Sun, Y. Deng, L. Bao, Q. Zhu, X. Zhang, Y. Zheng, C. Geng, X. Chai, R. He, X. Li, Q. Lv, H. Zhu, W. Deng, Y. Xu, Y. Wang, L. Qiao, Y. Tan, L. Song, G. Wang, X. Du, N. Gao, J. Liu, J. Xiao, X. D. Su, Z. Du, Y. Feng, C. Qin, C. Qin, R. Jin, $X$. S. Xie, Potent neutralizing antibodies against SARS-CoV-2 identified by highthroughput single-cell sequencing of convalescent patients' B cells. Cell 182, 7384.e16 (2020). doi:10.1016/j.cell.2020.05.025 Medline

6. S. J. Zost, P. Gilchuk, R. E. Chen, J. B. Case, J. X. Reidy, A. Trivette, R. S. Nargi, R. E. Sutton, N. Suryadevara, E. C. Chen, E. Binshtein, S. Shrihari, M. Ostrowski, H. Y. Chu, J. E. Didier, K. W. MacRenaris, T. Jones, S. Day, L. Myers, F. Eun-Hyung Lee, D. C. Nguyen, I. Sanz, D. R. Martinez, P. W. Rothlauf, L.-M. Bloyet, S. P. J. Whelan, R. S. Baric, L. B. Thackray, M. S. Diamond, R. H. Carnahan, J. E. Crowe Jr., Rapid isolation and profiling of a diverse panel of human monoclonal antibodies targeting the SARS-CoV-2 spike protein. Nat. Med. 26, 1422-1427 (2020). doi:10.1038/s41591-020-0998-x Medline

7. D. F. Robbiani, C. Gaebler, F. Muecksch, J. C. C. Lorenzi, Z. Wang, A. Cho, M. Agudelo, C. O. Barnes, A. Gazumyan, S. Finkin, T. Hägglöf, T. Y. Oliveira, C. Viant, A. Hurley, H.-H. Hoffmann, K. G. Millard, R. G. Kost, M. Cipolla, K. Gordon, F. Bianchini, S. T. Chen, V. Ramos, R. Patel, J. Dizon, I. Shimeliovich, P. Mendoza, H. Hartweger, L. Nogueira, M. Pack, J. Horowitz, F. Schmidt, Y. Weisblum, E. Michailidis, A. W. Ashbrook, E. Waltari, J. E. Pak, K. E. Huey-Tubman, N. Koranda,
P. R. Hoffman, A. P. West Jr., C. M. Rice, T. Hatziioannou, P. J. Bjorkman, P. D. Bieniasz, M. Caskey, M. C. Nussenzweig, Convergent antibody responses to SARS-CoV-2 in convalescent individuals. Nature 584, 437-442 (2020). doi:10.1038/s41586-020-2456-9 Medline

8. J. Hansen, A. Baum, K. E. Pascal, V. Russo, S. Giordano, E. Wloga, B. O. Fulton, Y. Yan, K. Koon, K. Patel, K. M. Chung, A. Hermann, E. Ullman, J. Cruz, A. Rafique, T. Huang, J. Fairhurst, C. Libertiny, M. Malbec, W. Y. Lee, R. Welsh, G. Farr, S. Pennington, D. Deshpande, J. Cheng, A. Watty, P. Bouffard, R. Babb, N. Levenkova, C. Chen, B. Zhang, A. Romero Hernandez, K. Saotome, Y. Zhou, M. Franklin, S. Sivapalasingam, D. C. Lye, S. Weston, J. Logue, R. Haupt, M. Frieman, G. Chen, W. Olson, A. J. Murphy, N. Stahl, G. D. Yancopoulos, C. A. Kyratsous, Studies in humanized mice and convalescent humans yield a SARS-CoV-2 antibody cocktail. Science 369, 1010-1014 (2020). doi:10.1126/science.abd0827 Medline

9. A. Baum, B. O. Fulton, E. Wloga, R. Copin, K. E. Pascal, V. Russo, S. Giordano, K. Lanza, N. Negron, M. Ni, Y. Wei, G. S. Atwal, A. J. Murphy, N. Stahl, G. D. Yancopoulos, C. A. Kyratsous, Antibody cocktail to SARS-CoV-2 spike protein prevents rapid mutational escape seen with individual antibodies. Science 369 , 1014-1018 (2020). doi:10.1126/science.abd0831 Medline

10. L. Liu, P. Wang, M. S. Nair, J. Yu, M. Rapp, Q. Wang, Y. Luo, J. F. Chan, V. Sahi, A. Figueroa, X. V. Guo, G. Cerutti, J. Bimela, J. Gorman, T. Zhou, Z. Chen, K. Y. Yuen, P. D. Kwong, J. G. Sodroski, M. T. Yin, Z. Sheng, Y. Huang, L. Shapiro, D. D. Ho, Potent neutralizing antibodies directed to multiple epitopes on SARS-CoV-2 spike. Nature 584, 450-456 (2020). doi:10.1038/s41586-020-2571-7 Medline

11. E. Seydoux, L. J. Homad, A. J. MacCamy, K. R. Parks, N. K. Hurlburt, M. F. Jennewein, N. R. Akins, A. B. Stuart, Y.-H. Wan, J. Feng, R. E. Whaley, S. Singh, M. Boeckh, K. W. Cohen, M. J. McElrath, J. A. Englund, H. Y. Chu, M. Pancera, A. T. McGuire, L. Stamatatos, Analysis of a SARS-CoV-2-infected individual reveals development of potent neutralizing antibodies with limited somatic mutation. Immunity 53, 98-105.e5 (2020). doi:10.1016/i.immuni.2020.06.001 Medline

12. R. Shi, C. Shan, X. Duan, Z. Chen, P. Liu, J. Song, T. Song, X. Bi, C. Han, L. Wu, G. Gao, X. Hu, Y. Zhang, Z. Tong, W. Huang, W. J. Liu, G. Wu, B. Zhang, L. Wang, J. Qi, H. Feng, F.-S. Wang, Q. Wang, G. F. Gao, Z. Yuan, J. Yan, A human neutralizing antibody targets the receptor-binding site of SARS-CoV-2. Nature 584, 120-124 (2020). doi:10.1038/s41586-020-2381-y Medline

13. V. J. Munster, F. Feldmann, B. N. Williamson, N. van Doremalen, L. Pérez-Pérez, J. Schulz, K. Meade-White, A. Okumura, J. Callison, B. Brumbaugh, V. A. Avanzato, R. Rosenke, P. W. Hanley, G. Saturday, D. Scott, E. R. Fischer, E. de Wit, Respiratory disease in rhesus macaques inoculated with SARS-CoV-2. Nature 585, 268-272 (2020). doi:10.1038/s41586-020-2324-7 Medline

14. C. Shan, Y.-F. Yao, X.-L. Yang, Y.-W. Zhou, G. Gao, Y. Peng, L. Yang, X. Hu, J. Xiong, R.-D. Jiang, H.-J. Zhang, X.-X. Gao, C. Peng, J. Min, Y. Chen, H.-R. Si, J. Wu, P. Zhou, Y.-Y. Wang, H.-P. Wei, W. Pang, Z.-F. Hu, L.-B. Lv, Y.-T. Zheng, Z.-L. Shi, Z.-M. Yuan, Infection with novel coronavirus (SARS-CoV-2) causes pneumonia in Rhesus macaques. Cell Res. 30, 670-677 (2020). doi:10.1038/s41422-020-0364-z Medline

15. J. Yu, L. H. Tostanoski, L. Peter, N. B. Mercado, K. McMahan, S. H. Mahrokhian, J. P. Nkolola, J. Liu, Z. Li, A. Chandrashekar, D. R. Martinez, C. Loos, C. Atyeo, S. Fischinger, J. S. Burke, M. D. Slein, Y. Chen, A. Zuiani, F. J. N. Lelis, M. Travers, S. Habibi, L. Pessaint, A. Van Ry, K. Blade, R. Brown, A. Cook, B. Finneyfrock, A. Dodson, E. Teow, J. Velasco, R. Zahn, F. Wegmann, E. A. Bondzie, G. Dagotto, M. S. Gebre, X. He, C. Jacob-Dolan, M. Kirilova, N. Kordana, Z. Lin, L. F. Maxfield, F. Nampanya, R. Nityanandam, J. D. Ventura, H. Wan, Y. Cai, B. Chen, A. G. Schmidt, D. R. Wesemann, R. S. Baric, G. Alter, H. Andersen, M. G. Lewis, D. H. Barouch, DNA vaccine protection against SARS-CoV-2 in rhesus macaques. Science 369, 806-811 (2020). doi:10.1126/science.abc6284 Medline

16. A. Chandrashekar, J. Liu, A. J. Martinot, K. McMahan, N. B. Mercado, L. Peter, L. H. Tostanoski, J. Yu, Z. Maliga, M. Nekorchuk, K. Busman-Sahay, M. Terry, L. M. Wrijil, S. Ducat, D. R. Martinez, C. Atyeo, S. Fischinger, J. S. Burke, M. D. Slein, L. Pessaint, A. Van Ry, J. Greenhouse, T. Taylor, K. Blade, A. Cook, B. Finneyfrock, R. Brown, E. Teow, J. Velasco, R. Zahn, F. Wegmann, P. Abbink, E. A. Bondzie, G. Dagotto, M. S. Gebre, X. He, C. Jacob-Dolan, N. Kordana, Z. Li, M. A. Lifton, S. H. Mahrokhian, L. F. Maxfield, R. Nityanandam, J. P. Nkolola, A. G. Schmidt, A. D. Miller, R. S. Baric, G. Alter, P. K. Sorger, J. D. Estes, H. Andersen, M. G. Lewis, D. H. Barouch, SARS-CoV-2 infection protects against rechallenge in rhesus macaques. 
Science 369, 812-817 (2020). doi:10.1126/science.abc4776 Medline

17. W. Deng, L. Bao, J. Liu, C. Xiao, J. Liu, J. Xue, Q. Lv, F. Qi, H. Gao, P. Yu, Y. Xu, Y. Qu, F. Li, Z. Xiang, H. Yu, S. Gong, M. Liu, G. Wang, S. Wang, Z. Song, Y. Liu, W. Zhao, Y. Han, L. Zhao, X. Liu, Q. Wei, C. Qin, Primary exposure to SARS-CoV-2 protects against reinfection in rhesus macaques. Science 369, 818-823 (2020). doi:10.1126/science. abc5343 Medline

18. N. B. Mercado, R. Zahn, F. Wegmann, C. Loos, A. Chandrashekar, J. Yu, J. Liu, L. Peter, K. McMahan, L. H. Tostanoski, X. He, D. R. Martinez, L. Rutten, R. Bos, D. van Manen, J. Vellinga, J. Custers, J. P. Langedijk, T. Kwaks, M. J. G. Bakkers, D. Zuijdgeest, S. K. Rosendahl Huber, C. Atyeo, S. Fischinger, J. S. Burke, J. Feldman, B. M. Hauser, T. M. Caradonna, E. A. Bondzie, G. Dagotto, M. S. Gebre, E. Hoffman, C. Jacob-Dolan, M. Kirilova, Z. Li, Z. Lin, S. H. Mahrokhian, L. F. Maxfield, F. Nampanya, R. Nityanandam, J. P. Nkolola, S. Patel, J. D. Ventura, K. Verrington, H. Wan, L. Pessaint, A. Van Ry, K. Blade, A. Strasbaugh, M. Cabus, R. Brown, A. Cook S. Zouantchangadou, E. Teow, H. Andersen, M. G. Lewis, Y. Cai, B. Chen, A. G. Schmidt, R. K. Reeves, R. S. Baric, D. A. Lauffenburger, G. Alter, P. Stoffels, M. Mammen, J. Van Hoof, H. Schuitemaker, D. H. Barouch, Single-shot Ad26 vaccine protects against SARS-CoV-2 in rhesus macaques. Nature 10.1038/s41586-0202607-z (2020). doi:10.1038/s41586-020-2607-z Medline

19. K. S. Corbett, B. Flynn, K. E. Foulds, J. R. Francica, S. Boyoglu-Barnum, A. P. Werner, B. Flach, S. O'Connell, K. W. Bock, M. Minai, B. M. Nagata, H. Andersen, D. R. Martinez, A. T. Noe, N. Douek, M. M. Donaldson, N. N. Nji, G. S. Alvarado, D. K. Edwards, D. R. Flebbe, E. Lamb, N. A. Doria-Rose, B. C. Lin, M. K. Louder, S. O'Dell, S. D. Schmidt, E. Phung, L. A. Chang, C. Yap, J. M. Todd, L. Pessaint, A. Van Ry, S. Browne, J. Greenhouse, T. Putman-Taylor, A. Strasbaugh, T.-A. Campbell, A. Cook, A. Dodson, K. Steingrebe, W. Shi, Y. Zhang, O. M. Abiona, L. Wang, A. Pegu, E. S. Yang, K. Leung, T. Zhou, I.-T. Teng, A. Widge, I. Gordon, L. Novik, R. A. Gillespie, R. J. Loomis, J. I. Moliva, G. Stewart-Jones, S. Himansu, W.-P. Kong, M. C. Nason, K. M. Morabito, T. J. Ruckwardt, J. E. Ledgerwood, M. R. Gaudinski, P. D. Kwong, J. R. Mascola, A. Carfi, M. G. Lewis, R. S. Baric, A. McDermott, I. N. Moore, N. J. Sullivan, M. Roederer, R. A. Seder, B. S. Graham, Evaluation of the mRNA1273 vaccine against SARS-CoV-2 in nonhuman primates. N. Engl. J. Med. NEJMoa2024671 (2020). doi:10.1056/NEJMoa2024671 Medline

20. N. van Doremalen, T. Lambe, A. Spencer, S. Belij-Rammerstorfer, J. N. Purushotham, J. R. Port, V. A. Avanzato, T. Bushmaker, A. Flaxman, M. Ulaszewska, F. Feldmann, E. R. Allen, H. Sharpe, J. Schulz, M. Holbrook, A. Okumura, K. Meade-White, L. Pérez-Pérez, N. J. Edwards, D. Wright, C. Bissett, C. Gilbride, B. N. Williamson, R. Rosenke, D. Long, A. Ishwarbhai, R. Kailath, L. Rose, S. Morris, C. Powers, J. Lovaglio, P. W. Hanley, D. Scott, G. Saturday, E. de Wit, S. C. Gilbert, V. J. Munster, ChAdOx1 nCoV-19 vaccine prevents SARS-CoV-2 pneumonia in rhesus macaques. Nature 10.1038/s41586-020-2608-y (2020). doi:10.1038/s41586-020-2608-y Medline

21. S. F. Sia, L.-M. Yan, A. W. H. Chin, K. Fung, K.-T. Choy, A. Y. L. Wong, P. Kaewpreedee, R. A. P. M. Perera, L. L. M. Poon, J. M. Nicholls, M. Peiris, H.-L. Yen, Pathogenesis and transmission of SARS-CoV-2 in golden hamsters. Nature 583, 834-838 (2020). doi:10.1038/s41586-020-2342-5 Medline

22. M. Imai, K. Iwatsuki-Horimoto, M. Hatta, S. Loeber, P. J. Halfmann, N. Nakajima, T. Watanabe, M. Ujie, K. Takahashi, M. Ito, S. Yamada, S. Fan, S. Chiba, M. Kuroda, L. Guan, K. Takada, T. Armbrust, A. Balogh, Y. Furusawa, M. Okuda, H. Ueki, A. Yasuhara, Y. Sakai-Tagawa, T. J. S. Lopes, M. Kiso, S. Yamayoshi, N. Kinoshita, N. Ohmagari, S. I. Hattori, M. Takeda, H. Mitsuya, F. Krammer, T. Suzuki, Y. Kawaoka, Syrian hamsters as a small animal model for SARS-CoV-2 infection and countermeasure development. Proc. Natl. Acad. Sci. U.S.A. 117, 16587-16595 (2020). doi:10.1073/pnas.2009799117 Medline

23. T. F. Rogers, F. Zhao, D. Huang, N. Beutler, A. Burns, W. T. He, O. Limbo, C. Smith, G. Song, J. Woehl, L. Yang, R. K. Abbott, S. Callaghan, E. Garcia, J. Hurtado, M. Parren, L. Peng, S. Ramirez, J. Ricketts, M. J. Ricciardi, S. A. Rawlings, N. C. Wu, M. Yuan, D. M. Smith, D. Nemazee, J. R. Teijaro, J. E. Voss, I. A. Wilson, R. Andrabi, B. Briney, E. Landais, D. Sok, J. G. Jardine, D. R. Burton, Isolation of potent SARSCoV-2 neutralizing antibodies and protection from disease in a small animal model. Science 369, 956-963 (2020). doi:10.1126/science.abc7520 Medline

24. L. Zou, F. Ruan, M. Huang, L. Liang, H. Huang, Z. Hong, J. Yu, M. Kang, Y. Song, J. Xia, Q. Guo, T. Song, J. He, H.-L. Yen, M. Peiris, J. Wu, SARS-CoV-2 viral load in upper respiratory specimens of infected patients. N. Engl. J. Med. 382, 1177-1179 (2020). doi:10.1056/NEJMc2001737 Medline
25. X. He, E. H. Y. Lau, P. Wu, X. Deng, J. Wang, X. Hao, Y. C. Lau, J. Y. Wong, Y. Guan, X. Tan, X. Mo, Y. Chen, B. Liao, W. Chen, F. Hu, Q. Zhang, M. Zhong, Y. Wu, L. Zhao, F. Zhang, B. J. Cowling, F. Li, G. M. Leung, Temporal dynamics in viral shedding and transmissibility of COVID-19. Nat. Med. 26, 672-675 (2020). doi:10.1038/s41591-020-0869-5 Medline

26. Q. Gao, L. Bao, H. Mao, L. Wang, K. Xu, M. Yang, Y. Li, L. Zhu, N. Wang, Z. Lv, H. Gao, X. Ge, B. Kan, Y. Hu, J. Liu, F. Cai, D. Jiang, Y. Yin, C. Qin, J. Li, X. Gong, X. Lou, W. Shi, D. Wu, H. Zhang, L. Zhu, W. Deng, Y. Li, J. Lu, C. Li, X. Wang, W. Yin, Y. Zhang, C. Qin, Development of an inactivated vaccine candidate for SARS-CoV-2. Science 369, 77-81 (2020). doi:10.1126/science.abc1932 Medline

27. A. Patel, J. Walters, E. L. Reuschel, K. Schultheis, E. Parzych, E. N. Gary, I. Maricic, M. Purwar, Z. Eblimit, S. N. Walker, D. Guimet, P. Bhojnagarwala, A. Doan, Z. Xu, D. Elwood, S. M. Reeder, L. Pessaint, K. Y. Kim, A. Cook, N. Chokkalingam, B. Finneyfrock, E. Tello-Ruiz, A. Dodson, J. Choi, A. Generotti, J. Harrison, N. J. Tursi, V. M. Andrade, Y. Dia, F. I. Zaidi, H. Andersen, M. G. Lewis, K. Muthumani, J. Kim, D. W. Kulp, L. M. Humeau, S. Ramos, T. R. F. Smith, D. B. Weiner, K. E. Broderick, Intradermal-delivered DNA vaccine provides anamnestic protection in a rhesus macaque SARS-CoV-2 challenge model. bioRxiv 2020.07.28.225649 [Preprint]. 29 July 2020; https://doi.org/10.1101/2020.07.28.225649.

28. B. N. Williamson, F. Feldmann, B. Schwarz, K. Meade-White, D. P. Porter, J. Schulz, N. van Doremalen, I. Leighton, C. K. Yinda, L. Pérez-Pérez, A. Okumura, J. Lovaglio, P. W. Hanley, G. Saturday, C. M. Bosio, S. Anzick, K. Barbian, T. Cihlar, C. Martens, D. P. Scott, V. J. Munster, E. de Wit, Clinical benefit of remdesivir in rhesus macaques infected with SARS-CoV-2. Nature 585, 273-276 (2020). doi:10.1038/s41586-020-2423-5 Medline

29. S. Wang, Y. Peng, R. Wang, S. Jiao, M. Wang, W. Huang, C. Shan, W. Jiang, Z. Li, C. Gu, X. H. Ben Chen, Y. Yao, J. Min, H. Zhang, Y. Chen, G. Gao, P. Tang, G. Li, A. Wang, L. Wang, S. Chen, X. Gui, J. Zhang, Z. Yuan, D. Liu, An antibody-dependent enhancement (ADE) activity eliminated neutralizing antibody with potent prophylactic and therapeutic efficacy against SARS-CoV-2 in rhesus monkeys. bioRxiv 2020.07.26.222257 [Preprint]. 27 July 2020; https://doi.org/10.1101/2020.07.26.222257.

30. L. Li, W. Zhang, Y. Hu, X. Tong, S. Zheng, J. Yang, Y. Kong, L. Ren, Q. Wei, H. Mei, C. Hu, C. Tao, R. Yang, J. Wang, Y. Yu, Y. Guo, X. Wu, Z. Xu, L. Zeng, N. Xiong, L. Chen, J. Wang, N. Man, Y. Liu, H. Xu, E. Deng, X. Zhang, C. Li, C. Wang, S. Su, L. Zhang, J. Wang, Y. Wu, Z. Liu, Effect of convalescent plasma therapy on time to clinical improvement in patients with severe and life-threatening COVID-19: A randomized clinical trial. JAMA 324, 460-470 (2020). doi:10.1001/jama.2020.10044 Medline

31. B. Korber, W. M. Fischer, S. Gnanakaran, H. Yoon, J. Theiler, W. Abfalterer, N. Hengartner, E. E. Giorgi, T. Bhattacharya, B. Foley, K. M. Hastie, M. D. Parker, D. G. Partridge, C. M. Evans, T. M. Freeman, T. I. de Silva, C. McDanal, L. G. Perez, H. Tang, A. Moon-Walker, S. P. Whelan, C. C. LaBranche, E. O. Saphire, D. C. Montefiori, Sheffield COVID-19 Genomics Group, Tracking changes in SARS-CoV2 spike: Evidence that D614G increases infectivity of the COVID-19 virus. Cell 182 , 812-827.e19 (2020). doi:10.1016/i.cell.2020.06.043 Medline

32. Y. Toyoshima, K. Nemoto, S. Matsumoto, Y. Nakamura, K. Kiyotani, SARS-CoV-2 genomic variations associated with mortality rate of COVID-19. J. Hum. Genet. 10.1038/s10038-020-0808-9 (2020). doi:10.1038/s10038-020-0808-9 Medline

33. E. M. Volz, V. Hill, J. T. McCrone, A. Price, D. Jorgensen, A. O'Toole, J. A. Southgate, R. Johnson, B. Jackson, F. F. Nascimento, S. M. Rey, S. M. Nicholls, R. M. Colquhoun, A. da Silva Filipe, J. G. Shepherd, D. J. Pascall, R. Shah, N. Jesudason, K. Li, R. Jarrett, N. Pacchiarini, M. Bull, L. Geidelberg, I. Siveroni, I. G. Goodfellow, N. J. Loman, O. Pybus, D. L. Robertson, E. C. Thomson, A. Rambaut, T. R. Connor, The COVID-19 Genomics UK Consortium, Evaluating the effects of SARS-CoV-2 spike mutation D614G on transmissibility and pathogenicity. medRxiv 2020.07.31.20166082 [Preprint]. 1 September 2020; https://doi.org/10.1101/2020.07.31.20166082.

34. B. W.-Y. Mok, C. J. Cremin, S.-Y. Lau, S. Deng, P. Chen, A. J. Zhang, A. C.-Y. Lee, H. Liu, S. Liu, T. T.-L. Ng, H.-Y. Lao, E. L.-K. Lee, K. S.-S. Leung, P. Wang, K. K.-W. To, J. F.-W. Chan, K.-H. Chan, K.-Y. Yuen, G. K.-H. Siu, H. Chen, SARS-CoV-2 spike D614G variant exhibits highly efficient replication and transmission in hamsters. bioRxiv 2020.08.28.271635 [Preprint]. 28 August 2020; https://doi.org/10.1101/2020.08.28.271635.

35. L. Yurkovetskiy, K. E. Pascal, C. Tompkins-Tinch, T. Nyalile, Y. Wang, A. Baum, W. 
E. Diehl, A. Dauphin, C. Carbone, K. Veinotte, S. B. Egri, S. F. Schaffner, J. E. Lemieux, J. Munro, P. C. Sabeti, C. Kyratsous, K. Shen, J. Luban, SARS-CoV-2 spike protein variant D614G increases infectivity and retains sensitivity to antibodies that target the receptor binding domain. bioRxiv 2020.07.04.187757 [Preprint]. 16 July 2020; https://doi.org/10.1101/2020.07.04.187757.

36. V. M. Corman, O. Landt, M. Kaiser, R. Molenkamp, A. Meijer, D. K. W. Chu, T. Bleicker, S. Brünink, J. Schneider, M. L. Schmidt, D. G. J. C. Mulders, B. L. Haagmans, B. van der Veer, S. van den Brink, L. Wijsman, G. Goderski, J.-L. Romette, J. Ellis, M. Zambon, M. Peiris, H. Goossens, C. Reusken, M. P. G. Koopmans, C. Drosten, Detection of 2019 novel coronavirus (2019-nCoV) by realtime RT-PCR. Euro Surveill. 25, 2000045 (2020). doi:10.2807/1560Z917.ES.2020.25.3.2000045 Medline

37. R. Wölfel, V. M. Corman, W. Guggemos, M. Seilmaier, S. Zange, M. A. Müller, D. Niemeyer, T. C. Jones, P. Vollmar, C. Rothe, M. Hoelscher, T. Bleicker, S. Brünink, J. Schneider, R. Ehmann, K. Zwirglmaier, C. Drosten, C. Wendtner, Virological assessment of hospitalized patients with COVID-2019. Nature 581, 465-469 (2020). doi:10.1038/s41586-020-2196-x Medline

\section{ACKNOWLEDGMENTS}

The following reagent was deposited by the Centers for Disease Control and Prevention and obtained through BEI Resources, NIAID, NIH: SARS-Related Coronavirus 2, Isolate USA-WA1/2020, NR-52281. Funding: A portion of this project has been funded in whole or in part with Federal funds from the Department of Health and Human Services; Office of the Assistant Secretary for Preparedness and Response; Biomedical Advanced Research and Development Authority, under OT number: HHSO100201700020C. Author contributions: A.B., N.S, A.J.M, G.D.Y., C.A.K. conceptualized and designed experiments. Y.G.G, J.D., E.C., H.S., C.B., B.K., O.G., E.D., L.P., M.P., A.C., R.B., V.A., J.G., T.T., performed experiments and A.B., R.C., D.A., A.O, K.A., R.C., M.G., H.A., M.G.L., M.A., G.D.Y., C.A.K. analyzed data. R.C., K.L., N.N., M.N., Y.W. prepared sequencing libraries and performed bioinformatics analysis A.B. and C.A.K. wrote the paper. C.A.K. acquired funding. Competing interests: Regeneron authors own options and/or stock of the company. This work has been described in one or more pending provisional patent applications. N.S, A.J.M., G.D.Y. and C.A.K. are officers of Regeneron. Data and Materials availability: All data are available in the main text or Supplementary Material. Regeneron materials described in this manuscript may be made available to qualified, academic, noncommercial researchers through a material transfer agreement upon request at https://regeneron.envisionpharma.com/vt regeneron/. For questions about how Regeneron shares materials, use the email address (preclinical.collaborations@ regeneron.com).

\section{SUPPLEMENTARY MATERIALS}

science.sciencemag.org/cgi/content/full/science.abe2402/DC1

Materials and Methods

Figs. S1 and S2

Tables S1 to 55

References $(36,37)$

MDAR Reproducibility Checklist

8 August 2020; accepted 7 October 2020

Published online 9 October 2020

10.1126/science.abe2402 
A

$\mathrm{mAb}$

$10933+10987$

prophylaxis virus end of study:
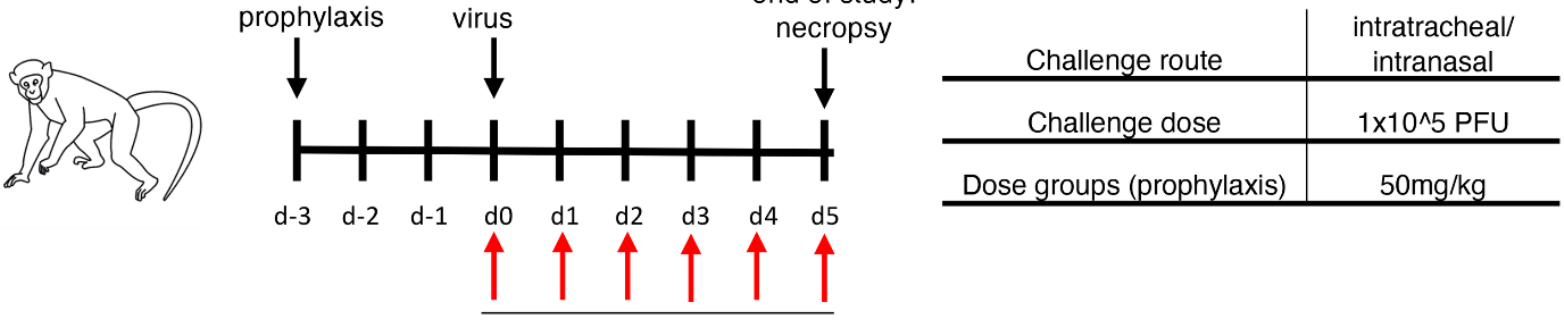

Viral load collection (NP swab)

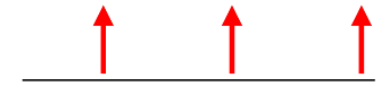

Viral load collection (BAL)

B

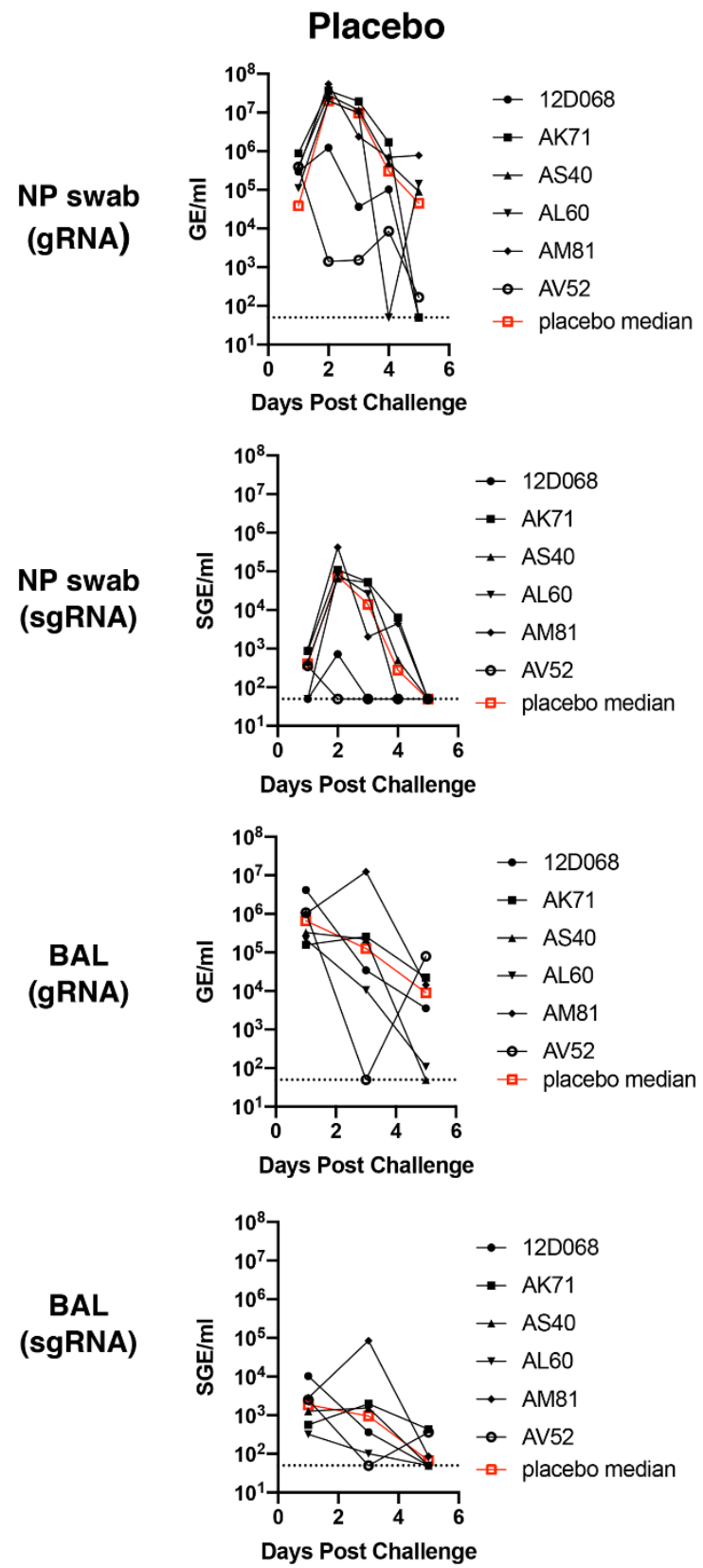

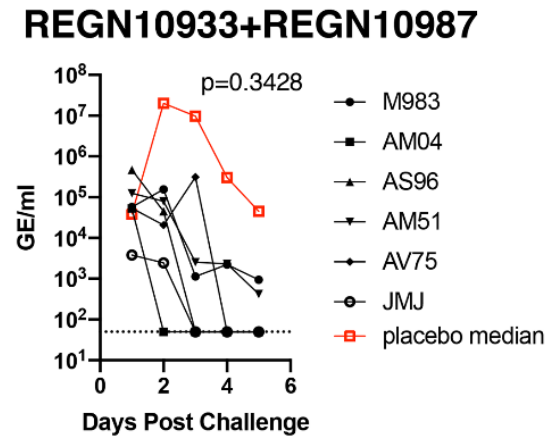
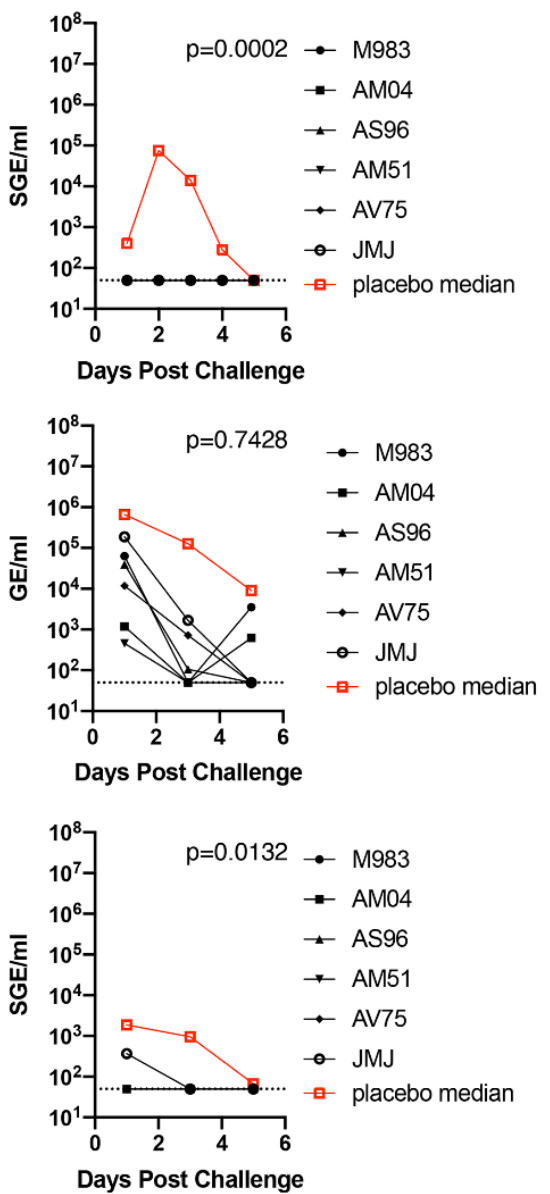
Fig. 1. Prophylactic efficacy of REGN-COV2 in the rhesus macaque model of SARS-CoV-2 infection (NHP Study \#1) (A) Overview of study design. (B) Impact of REGN-COV2 prophylaxis on viral genomic RNA (gRNA) and subgenomic RNA (sgRNA) in nasopharyngeal swabs and bronchioalveolar lavage (BAL) fluid. For detailed statistical analysis refer to tables S2 and S3. 
A

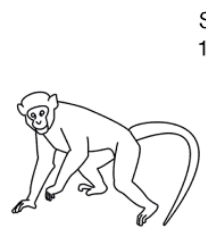

$\begin{array}{ccc}\text { Study A: mAb } & \text { Study B:mAb } & \\ \begin{array}{c}10933+10987 \\ \text { prophylaxis }\end{array} & \text { virus treatment } & \text { end of study: } \\ & & \text { necropsy }\end{array}$
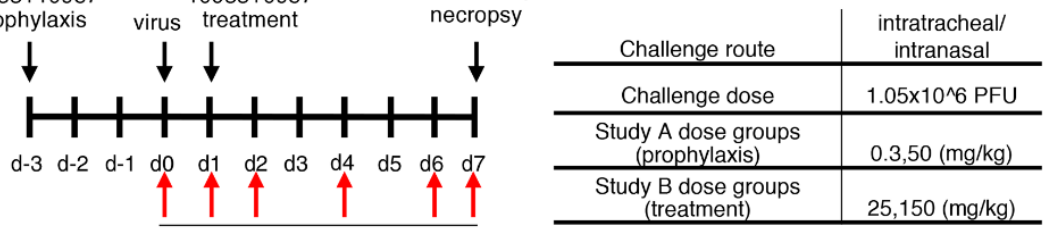

Viral load collection
(nasopharyngeal and oral swabs)

C

B

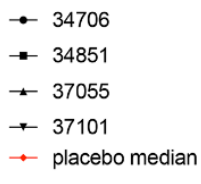

placebo
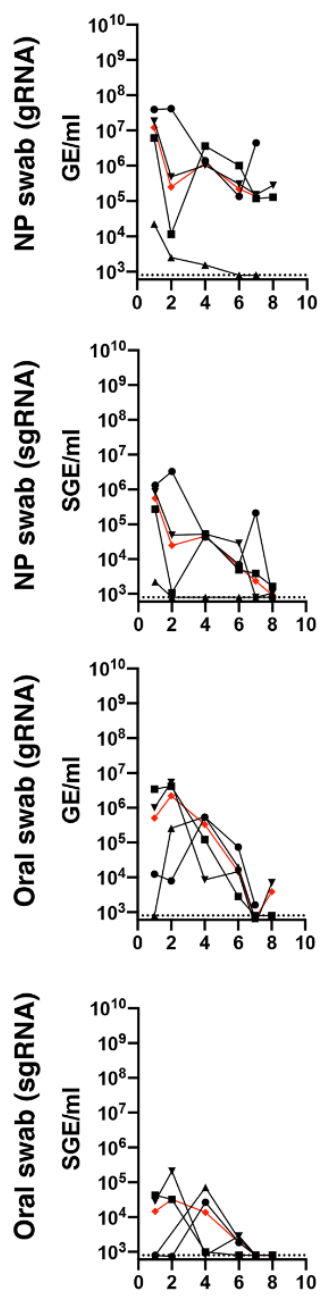

- 34946

- 36218

- 36839

$+37096$

$\rightarrow$ placebo median

$0.3 \mathrm{mg} / \mathrm{kg}$
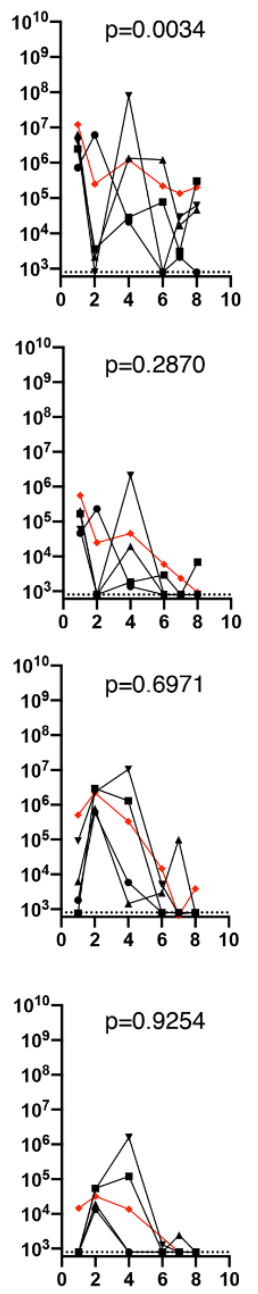

Days Post Challenge

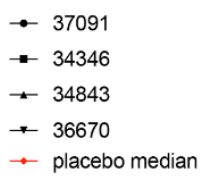

$50 \mathrm{mg} / \mathrm{kg}$
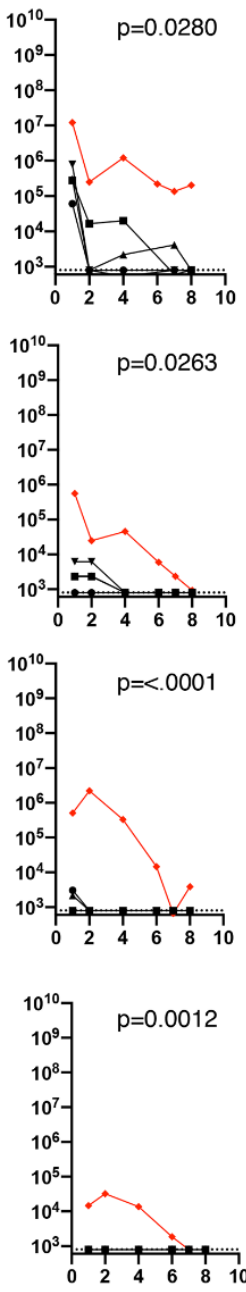

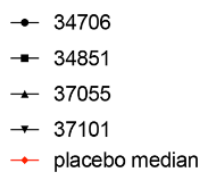

placebo
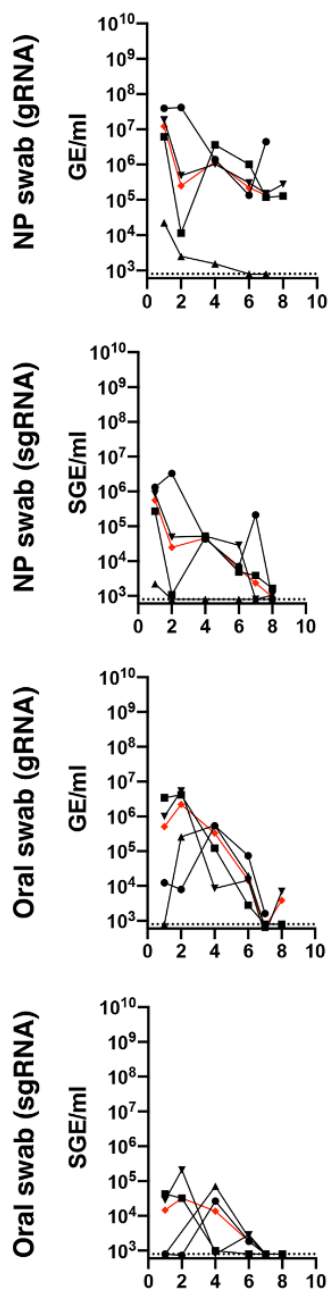
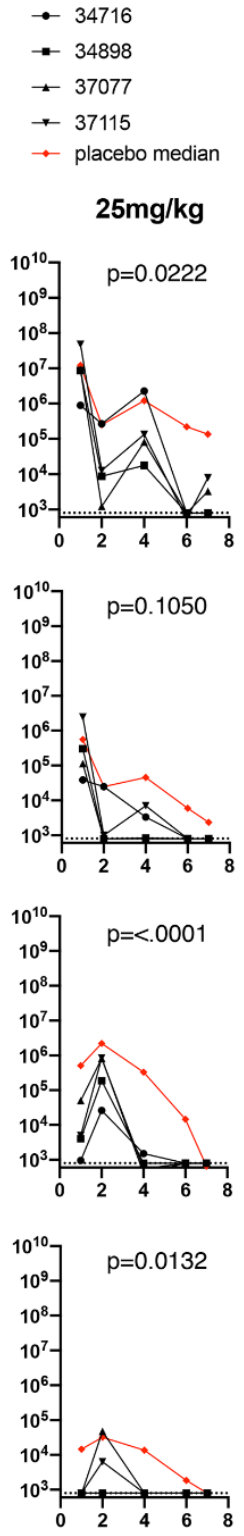

Days Post Challenge

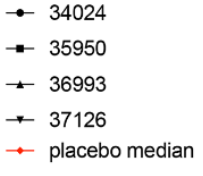

$150 \mathrm{mg} / \mathrm{kg}$
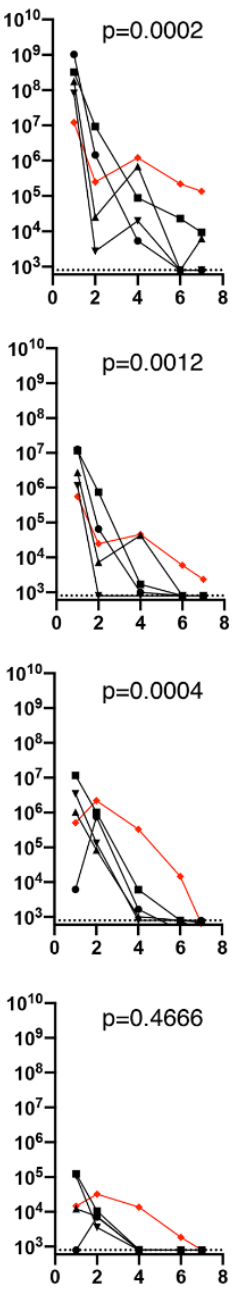

placebo
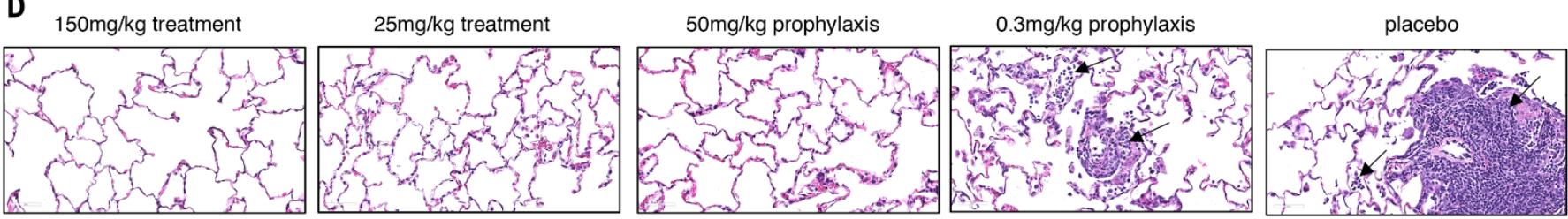
Fig. 2. Prophylactic and therapeutic efficacy of REGN-COV2 in the rhesus macaque model of SARS-CoV-2 infection (NHP Study \#2) (A) Overview of study design. (B) Impact of REGN-COV2 prophylaxis on viral genomic RNA (gRNA) and subgenomic RNA (sgRNA) in nasopharyngeal swabs and oral swabs [Study $A$, as shown in (A)]. (C) Impact of REGN-COV2 treatment on viral genomic RNA (gRNA) and subgenomic RNA (sgRNA) in nasopharyngeal swabs and oral swabs [Study B, as shown in (A)]. (D) representative images of histopathology in lungs of treated and placebo animals. For detailed statistical analysis refer to tables S2 and S3. 
A

Study A: mAb Study B: mAb

$10933+10987 \quad 10933+10987$

prophylaxis virus treatment
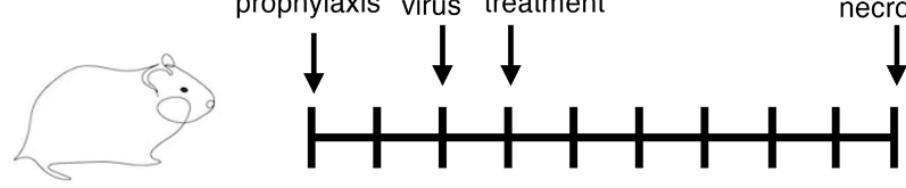

$\begin{array}{llllllllll}d-2 & d-1 & d 0 & d 1 & d 2 & d 3 & d 4 & d 5 & d 6 & d 7\end{array}$

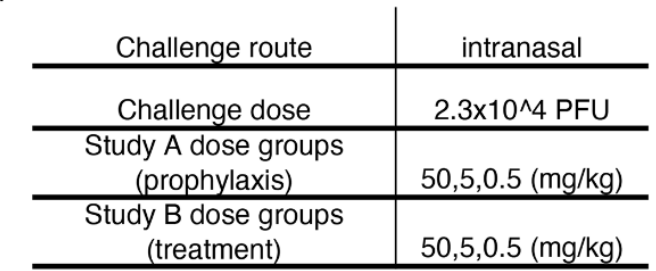

B

Prophylaxis

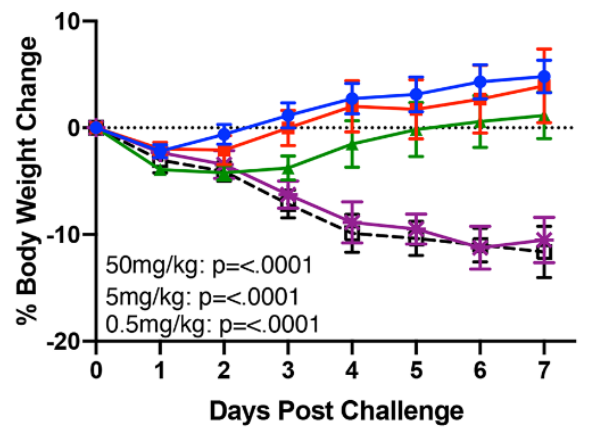

Treatment

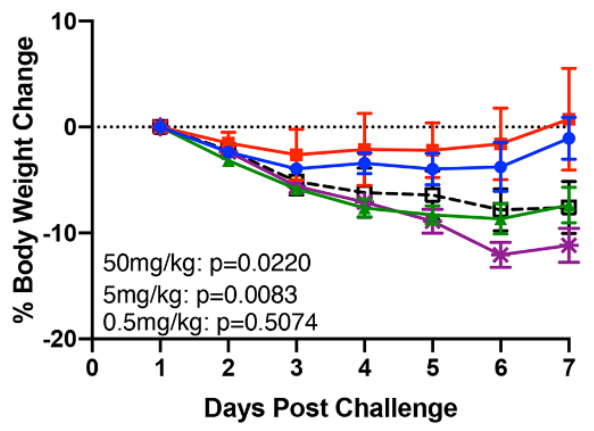

$\rightarrow$ REGN10933+REGN10987 (50mg/kg)

$\rightarrow$ REGN10933+REGN10987 (5mg/kg)

- REGN10933+REGN10987 (0.5mg/kg)

* IgG1 isotype control $50 \mathrm{mg} / \mathrm{kg}$

$\rightarrow$ - Placebo
C

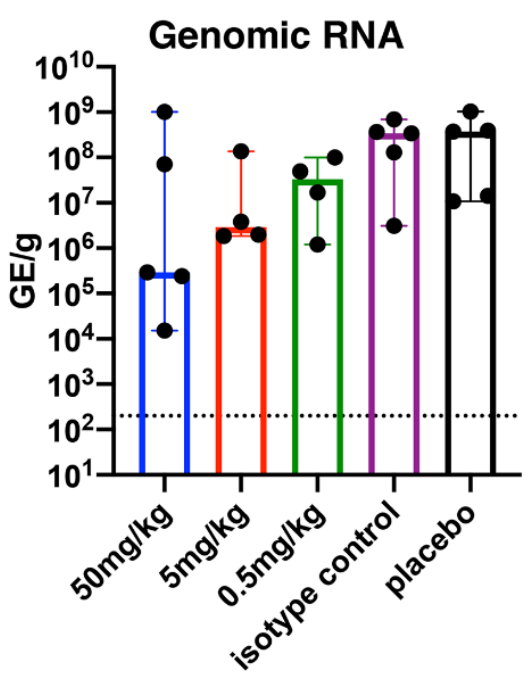

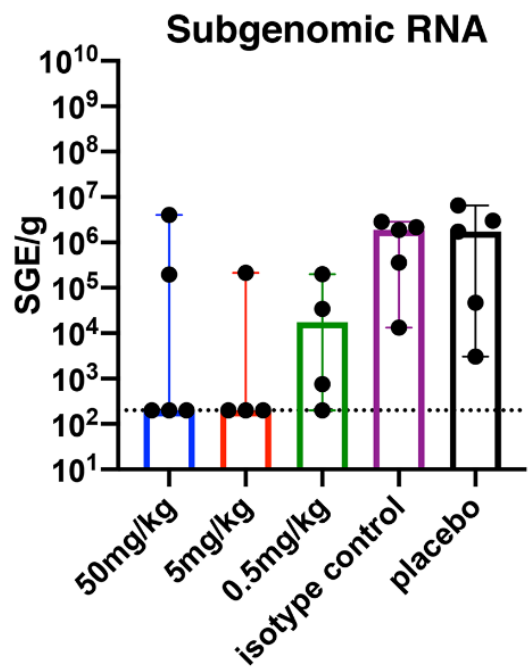

D

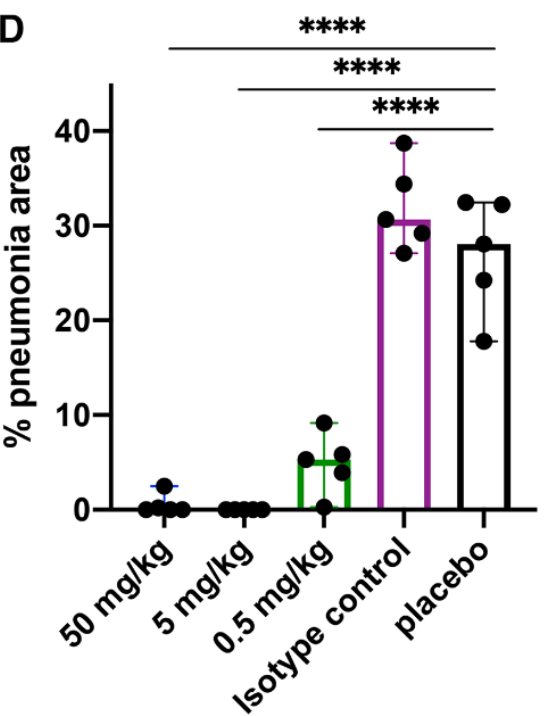

Fig. 3. Efficacy of REGN-COV2 in treatment and prophylaxis in the golden Syrian hamster model of SARS-CoV-2 infection. (A) Study design overview. (B) Impact of REGN-COV2 on weight loss in prophylaxis and treatment. (C) Impact of REGN-COV-2 prophylaxis on levels of gRNA and sgRNA in hamster lungs (7dpi). No statistical significance was observed between any treatment groups and placebo. (D) Impact of REGN-COV2 prophylaxis on percent area of lung exhibiting pathology typical of pneumonia (significant differences are denoted by: ${ }^{* * *} p<0.0001$ ). For detailed statistical analysis refer to tables S4 and S5. 